\title{
ASSESSMENT OF PERENNIAL RYEGRASS (LOLIUM PERENNE L.) GENOTYPES UNDER LATVIA AGRO-ECOLOGICAL CONDITIONS
}

\author{
*Sarmīte Rancāne, Ivo Vēzis, Dzidra Kreišmane, Aija Rebāne, Aldis Jansons \\ Latvia University of Life Sciences and Technologies, Latvia \\ *Corresponding author's email: sarmite.rancane@1lu.lv
}

\begin{abstract}
Within the frame of the Nordic/Baltic public-private partnership 'PPP for pre-breeding in perennial ryegrass' various activities were performed, including assessment of L. perenne (Lp) genotypes under agro-ecological conditions of Latvia. This article summarizes the data obtained in two harvest years for 19 intermediate tetraploid (4x) Lp genotypes. In order to compare the results obtained in ryegrass with performance of grass interspecies hybrids (Fl), which become especially relevant in the recent years, two varieties, developed in Latvia - Lolium $\times$ boucheanum Kunth. 'Saikava' and $\times$ Festulolium 'Vizule' were included in the experiment. Various scores were performed, including evaluation of regrowth, intensity of culm development, sward cover, crown rust (Puccinia coronata) susceptibility, etc. The dry matter yield (DMY) and fodder quality were also determined. It can be concluded that the genotypes showed relatively good results in the first two harvest years. Wintering conditions were favourable. Despite the intensified drought and heat in the $1^{\text {st }}$ ley year, relatively high DMY, which ranged from 9.30 to $12.15 \mathrm{t} \mathrm{ha}^{-1}$, for Lp were harvested in three cuts. In the $2^{\text {nd }}$ ley year, under more favourable humidity conditions, Lp in four cuts provided similar DMY, which ranged from 8.81 to $11.50 \mathrm{t} \mathrm{ha}^{-1}$. If we compare the average DMY of Lp and Fl genotypes, it can be concluded that in the first two harvest years no significant differences were found, the average DMY was 10.30 and $10.64 \mathrm{t} \mathrm{ha}^{-1}$, respectively. No significant differences were found between $\mathrm{Lp}$ and $\mathrm{Fl}$ in terms of forage quality.
\end{abstract}

Key words: festulolium, variety, dry matter yield, phenological assessment, fodder quality.

\section{Introduction}

Perennial ryegrass (Lolium perenne L.) is a very important species in providing a feed base for ruminants. It is high-yielding with excellent forage quality under frequent cutting regime; therefore, perennial ryegrass is the most important forage grass species in many regions with mild, humid climate. As the temperature is rising, it is expected that in near future the growing area of perennial ryegrass will expand to the north. In the Nordic-Baltic region perennial ryegrass becomes increasingly important, especially in view of the prospective climate changes. Currently, the cultivation of perennial ryegrass in Northern Europe is a challenge due to unstable wintering circumstances with blackfrost in winter and sharp temperature fluctuations in spring. Heat and drought periods in summer are also becoming more present and pronounced. It is of great importance to contribute to increasing the diversity of ryegrass genetic material in order to improve winter hardiness, persistence and stress tolerance of perennial ryegrass. For this purpose the researchers and breeders in the Nordic and Baltic countries joined their forces in collaboration within the long-term Public-Private Partnership (PPP) project on pre-breeding of perennial ryegrass (Rognli et al., 2019; Rancane et al., 2021). The PPP project aims to assess available genetic resources and develop new germplasm which can be used to develop resilient cultivars highly adaptable in new conditions. Current perennial ryegrass germplasm is probably restricted since the species is not native to the northern and continental regions (Rognli et al., 2013). The best strategy for future breeding could be hybridization of germplasm developed in northern countries with more exotic materials that allows to develop new varieties combining high yield potential, good winter survival and superior disease resistance (Helgadottir et al., 2018).

For increasing the genetic diversity of perennial ryegrass and improving its properties tetraploid forms are created. During the studies of the effect of variety ploidy and heading date on milk production and herbage intake of dairy cows it was found that later heading varieties had increased dry matter intakes (DMI) and milk production over intermediate heading varieties, but ploidy did not have a significant effect. Tetraploid swards had lower post-grazing sward heights than diploid swards but milk production did not differ significantly. Tetraploids exhibited significantly better graze-out performance than diploids. The proportion of tetraploid varieties in intensively grazed swards should be optimized. Breeding for improvements in grazing efficiency is possible which is confirmed by genetic variation between varieties within each ploidy (O’Donovan \& Delaby, 2005; McClearn et al., 2019; Tubritt et al., 2020). Increasing genome size during selective breeding process by whole genome duplication, changes the productivity and stress tolerance of new varieties. Lee at al. (2019) found that tetraploids exhibited a greater biomass under severe drought, whereas diploids had a greater biomass under the current rainfall and likely drought scenarios. Local climate forecasts will need to be taken into account when selecting new varieties, allowing for variable future reductions in precipitation. 
However, some grass breeders (Berzins et al., 2015, 2018; Nekrošas \& Kemešytè, 2007; Ostrem, Volden, \& Larsen, 2013) believe that under the climatic conditions of Northern Europe more promising is the development of interspecific (Festuca $\times$ Lolium) grass hybrids that allows to combine the best properties of both species in one variety. Forage nutritive value and the regrowth capacity of $\times$ Festulolium could make it as promising species for high-latitude regions (Ostrem, Novoa-Garrido, \& Larsen, 2013). Previous studies have shown that many varieties of $\times$ Festulolium have improved winter-hardiness and persistence in comparison with $L$. perenne (Lemežiene et al., 2004; Gutmane \& Adamovics, 2008; Ghesquiere, Humphreys, \& Zwierzykowski, 2010; Berzins et al., 2015). In Sweden, they found that the decline in dry matter yield at first harvest over three years was largest in perennial ryegrass, it was significantly less in loloid festulolium, while the smallest reduction in yield was found for festucoid festulolium (Halling, 2012). Research in this area is still lacking; therefore, in the experiment tetraploid $(4 \mathrm{x})$ perennial ryegrass varieties and accessions from different locations, and two local varieties of interspecific hybrids were included. The aim of the study was to compare and find the most productive and persistant perennial ryegrass varieties and accessions under Latvia agro-climatic conditions, and evaluate their performance in comparison with festulolium.

\section{Materials and Methods}

The field trials were conducted at the Research Institute of Agronomy ( $56^{\circ} 37 \mathrm{~N}, 25^{\circ} 07 \mathrm{E}$ ) of Latvia University of Life Sciences and Technologies. The experiment included 19 intermediate tetraploid (4x) perennial ryegrass (Lp) varieties and genebank accessions (hereinafter genotypes) and two grass interspecific hybrid (Fl) varieties developed in Latvia - the hybrid ryegrass (Lolium boucheanum Kunth.) 'Saikava' and festulolium $(\times$ Festulolium $)$
'Vizule'. Genotypes were randomized in two replicates. The size of the plot for each genotype in one replicate was $10 \mathrm{~m}^{2}$. The trial was established in June of 2018 in Eutric Retisol (WRB, 2014), granulometric composition was loamy sand, with $\mathrm{pH} \mathrm{KCl} 5.7$, organic matter $22 \mathrm{~g} \mathrm{~kg}^{-1}$, plant available phosphorus $\left(\mathrm{P}_{2} \mathrm{O}_{5}\right) 85 \mathrm{mg} \mathrm{kg}^{-1}$ and potassium $\left(\mathrm{K}_{2} \mathrm{O}\right) 95 \mathrm{mg} \mathrm{kg}^{-1}$. In the sowing year before establishment of experiment a fertiliser with $20 \mathrm{~kg} \mathrm{ha}^{-1} \mathrm{~N}$; $40 \mathrm{~kg} \mathrm{ha}^{-1} \mathrm{P}_{2} \mathrm{O}_{5}$ and $100 \mathrm{~kg} \mathrm{ha}^{-1} \mathrm{~K}_{2} \mathrm{O}$ (hereinafter 20-40-100 NPK) was applied. In the harvest years the following fertilisation scheme was used: 70-50-50 NPK in the spring after vegetation recovery; $\mathrm{N} 60$ after the $1^{\text {st }}$ and $2^{\text {nd }}$ mowing; 10-40-80 NPK after the last mowing in September. Thus, during each season, the total amount of fertiliser 200-90-130 NPK per season was applied.

During the season, various features for the ryegrass swards were scored visually, including: regrowth in spring and after harvesting; intensity of culm formation in the aftermath; crown rust (Puccinia coronata) susceptability; intensity of grass greening or grass health, etc. For the visual assessment, a 9-point scale was used: lower marks indicate a less pronounced trait expression, while higher marks indicate a more pronounced trait expression. Rust susceptibility was assessed according to the methodology of EUCARPIA Multisite Rust evaluation (Schubiger et al., 2010). A scale from point 1 to 9 was used, where: 1 - no rust disease, 2 - traces of rust, $3-5 \%$ of the leaf surface is covered with rust pustules, 4-10\%, 5-25\%, $6-40 \%, 7-60 \%, 8-75 \%, 9-$ more than $75 \%$ of the foliage covered with rust, the grass is dominated by necrotic leaves. The rating values represent a relative estimate of visual assessment of sward area in the plot occupied by rust pustules. The heading date, when first shoots emerged, was fixed and it was expressed as a number of days from the $1^{\text {st }}$ of May. The persistence or sward cover was determined by visual assessment of the proportion of area covered by perennial ryegrass plants, expressed in $\%$.

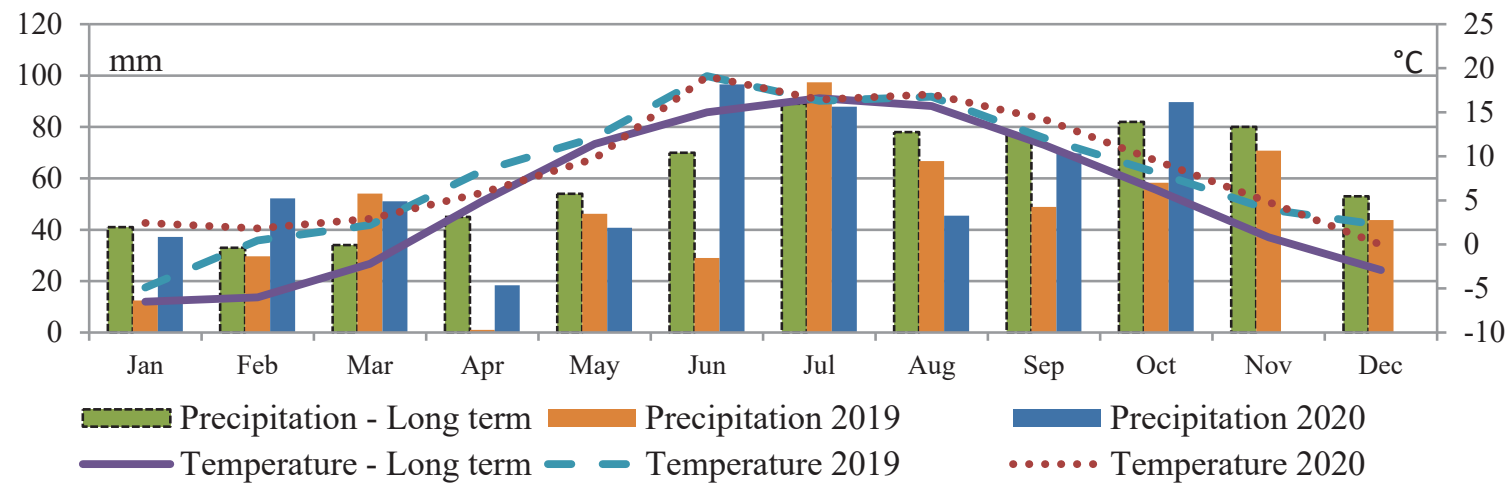

Figure 1. Amount of precipitation and average air temperature by months in 2019-2020 in comparison with long-term averages (Skriveri weather station data). 
The registration of DM yield was performed in three mowings in the $1^{\text {st }}$ ley year (2019) and four mowings in the $2^{\text {nd }}$ ley year (2020) using the experimental green mass harvester 'Haldrup'. To determine the DM content, the green mass samples, approximately 500 $\mathrm{g}$, from each plot before mowing were taken, weighed and placed in drying cabinets at $55^{\circ} \mathrm{C}$. Feed quality for dry matter samples was determined: crude protein (LVS EN ISO 5983-2: 2009); neutrally detergent fiber - NDF (LVS EN ISO16472: 2006); acid detergent fiber - ADF (LVS ENISO13906: 2008). Net energy for lactation (NEL), net energy for maintenance (NEM), net energy gain (NEG), DM digestibility, DM intake capacity (DMI) and relative feed value (RFV) were determined using the calculation methodology (Summary of feed..., 2013).

Results were analysed by ANOVA with a significance level of 0.05 . For the evaluation of data obtained, the tests of statistically significant differences $\left(\mathrm{LSD}_{0.05}\right)$ were used.

To characterize meteorological conditions, the amount of precipitation by months and the average monthly air temperatures are listed (Figure 1). In both, the $1^{\text {st }}$ ley year (2019) and the $2^{\text {nd }} l e y$ year (2020), the average air temperatures in winter and summer months were generally higher than the longterm averages. The exception was May of 2020, when the air temperature was below the long-term average, but this did not prevent grass growth. In terms of precipitation, the vegetation period of 2019 can be assessed as atypically dry - almost all months from April until the end of year, the monthly precipitation was well below the long-term averages. The season of 2020 also started with reduced rainfall: in April and May the amount of precipitation was well below the long-term average. In the following months of the season, precipitation normalized: June was rich in rainfall, when it fell by $30 \mathrm{~mm}$ more than usual. August was dry, but precipitation in September and October was similar to long-term averages. In general, the precipitation in vegetation period 2020 can be considered as typical.

\section{Results and Discussions}

In terms of heading time, perennial ryegrass genotypes differed within six days: the heading date

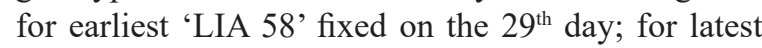
('Raminta', 'LVA02526' and 'LVA 1058') - on the $34^{\text {th }}$ day, calculating from the $1^{\text {st }}$ May. For most genotypes heading date was fixed on the $31^{\text {st }}-33^{\text {rd }}$ day, for interspecific hybrid varieties - 'Saikava' and 'Vizule' - on the $31^{\text {st }}$ day (Table 1).

Growth rate ranged from 6.4 to 9.0 points in spring and from 6.0 to 9.0 points after the $1^{\text {st }}$ cut (Table 1). The Lp 'Elena DS' and the hybrid ryegrass 'Saikava' grew more intensively both in spring and after mowing (scored with 9.0 points). Lp 'SW Birger' also grew rapidly (8.0). Lp 'EST 50' (8.0), 'Vir 51515' (7.5), 'Vir 50929' (7.5), 'Verseka' (7.5), 'Raite' (7.5) stood out in the $2^{\text {nd }}$ cut. Both interspecific hybrid varieties 'Saikava' and 'Vizule' also had intensive regrowth in the $2^{\text {nd }}$ cut ( 7.5 and 8.5 points). Intensive regrowth allows the variety to compete better with weeds and overcome other stressors, and usually it promotes higher yields.

The characteristic feature for $\mathrm{Lp}$ is more or less intensive development of generative shoots in aftermath, while Festuca hardly forms them (Berzins et al., 2019). With each subsequent mowing, the intensity of culm development decreases. In the $3^{\text {rd }}$ cut the intensity of culm development varied widely from 2.9 to 8.6 points. Particularly intensive culming was observed for Lp 'Elena DS' (8.6); several Lp genotypes were evaluated with 4.5 to 6.0 points. Very weak culm development in the $3^{\text {rd }}$ cut was noticed for 'Vir 51516' (2.9), 'EST 158' (3.0) and 'Garbor' (3.0). Genetic material with such characteristics could be used in the development of pasture and ornamental or lawn-type varieties. The intensity of culm development of interspecific hybrid varieties 'Saikava' and 'Vizule' in the $3^{\text {rd }}$ cut was assessed as moderately intensive, it ranged from 4.9 to 5.0 points.

In the first ley years perennial ryegrass persists relatively well, especially under favorable wintering conditions (Lemežiene et al., 2004; Berzins et al., 2018). In the years of the study, winters in Latvia were unusually warm, the average air temperature significantly exceeded the long-term averages (Figure 1 ), and there was no pronounced black-frost periods. The vegetation season of 2019 was extremely dry, which affected the growth rate, but not the persistence. The cover of the evaluated genotypes in the autumn of the $2^{\text {nd }}$ ley year ranged from $74 \%$ to $91 \%$. Significantly $(p<0.05)$ denser swards were formed by varieties 'Raite' and 'Vifelt', its coverage was $91 \%$. The most thinned was the sward of Lp 'Elena DS' (74\%). Varieties of interspecific hybrids 'Saikava' and 'Vizule' in the $2^{\text {nd }}$ ley year persisted well, the cover for both varieties was estimated as $81 \%$ (Table 1).

During the warm and wet seasons, ryegrass tends to be infected with various types of rust. This can be reduced by appropriate agronomic techniques, but experience shows that a very important role is played by genotype (Kemešyte, Statkevičiūte, \& Jaškūné, 2019). In the process of breeding material evaluation, high attention is paid to rust resistance. In the trial the susceptibility to crown rust was evaluated (1-9 points); therefore, the genotypes with lower marks have higher resistance. Ratings ranged from 2.0 to 6.5 points. More resistant to crown rust in the conditions of 2019 were Lp 'Ovambo' (2.0) and 'Vifelt' (2.1). For interspecific hybrids, rust susceptibility was 
Table 1

Assessment of $L$. perenne and $\times$ Festulolium varieties and genebank accessions in two ley years

\begin{tabular}{|c|c|c|c|c|c|c|c|}
\hline \multirow{2}{*}{ Genotypes } & \multirow{2}{*}{$\begin{array}{l}\text { Heading, } \\
\text { days from } \\
1^{\text {st }} \text { of May }\end{array}$} & \multicolumn{2}{|c|}{$\begin{array}{c}\text { Regrowth, points } \\
(1-9)\end{array}$} & \multirow{2}{*}{$\begin{array}{l}\text { Culms in } \\
\text { the } 3^{\text {rd }} \text { cut, } \\
\text { points }\end{array}$} & \multirow{2}{*}{$\begin{array}{c}\text { Sward } \\
\text { cover in the } \\
2^{\text {nd }} \mathrm{LY}^{* *}, \%\end{array}$} & \multirow{2}{*}{$\begin{array}{c}\text { Crown rust } \\
\text { susceptibility in } \\
\text { the } 3^{\text {rd }} \text { cut }\left(1^{\text {st }} L Y\right), \\
\text { points }\end{array}$} & \multirow{2}{*}{$\begin{array}{l}\text { Grass health } \\
\left(2^{\text {nd }} L Y\right), \\
\text { points }\end{array}$} \\
\hline & & in spring & $\begin{array}{l}\text { after the } \\
1^{\text {st }} \text { cut }\end{array}$ & & & & \\
\hline SW Birger & 31 & $8.0 b^{*}$ & $6.0 \mathrm{e}$ & $4.4 \mathrm{cde}$ & 83abcd & $3.5 \mathrm{bcd}$ & $6.2 \mathrm{abc}$ \\
\hline Raite & 33 & $7.0 \mathrm{~cd}$ & $7.5 \mathrm{bcd}$ & $4.5 \mathrm{bcde}$ & $91 \mathrm{a}$ & $4.6 \mathrm{ab}$ & $6.0 \mathrm{abc}$ \\
\hline Elena DS & 32 & $9.0 \mathrm{a}$ & $9.0 \mathrm{a}$ & $8.6 \mathrm{a}$ & $74 d$ & $3.6 \mathrm{bcd}$ & $6.4 \mathrm{abc}$ \\
\hline Alduva & 31 & $6.9 \mathrm{~cd}$ & $6.5 \mathrm{de}$ & $6.0 \mathrm{~b}$ & $80 \mathrm{bcd}$ & $3.6 \mathrm{bcd}$ & $5.9 \mathrm{abc}$ \\
\hline Verseka & 31 & $7.6 \mathrm{bc}$ & $7.5 \mathrm{bcd}$ & $5.1 \mathrm{bc}$ & $79 \mathrm{bcd}$ & $4.9 \mathrm{ab}$ & $4.6 \mathrm{~cd}$ \\
\hline Garbor & 31 & $6.5 \mathrm{~d}$ & $6.5 \mathrm{de}$ & $3.0 \mathrm{e}$ & $80 \mathrm{bcd}$ & $2.6 \mathrm{~cd}$ & $5.3 \mathrm{abcd}$ \\
\hline Ovambo & 32 & $7.0 \mathrm{~cd}$ & $6.5 \mathrm{de}$ & $3.1 \mathrm{de}$ & $88 \mathrm{ab}$ & $2.0 \mathrm{~d}$ & $7.1 \mathrm{a}$ \\
\hline Vifelt & 32 & $7.1 \mathrm{~cd}$ & $6.5 \mathrm{de}$ & $4.5 \mathrm{bcde}$ & $91 \mathrm{a}$ & $2.1 \mathrm{~d}$ & $6.1 \mathrm{abc}$ \\
\hline LIA 58 & 29 & $7.1 \mathrm{~cd}$ & $6.5 \mathrm{de}$ & $3.5 \mathrm{cde}$ & $76 \mathrm{~cd}$ & $3.3 \mathrm{bcd}$ & 5.4abcd \\
\hline Vir 50774 & 31 & $6.9 \mathrm{~cd}$ & $6.5 \mathrm{de}$ & $5.0 \mathrm{bc}$ & 81abcd & $2.6 \mathrm{~cd}$ & 5.0abcd \\
\hline EST 158 & 33 & $7.4 \mathrm{bc}$ & 7.0cde & $3.0 \mathrm{e}$ & $79 \mathrm{bcd}$ & $3.2 \mathrm{bcd}$ & $5.2 \mathrm{abcd}$ \\
\hline Vir 51515 & 33 & $7.5 \mathrm{bc}$ & $7.5 \mathrm{bcd}$ & $4.4 \mathrm{bcde}$ & 81abcd & $4.4 \mathrm{bc}$ & 5.4abcd \\
\hline EST 50 & 33 & $6.4 \mathrm{~d}$ & $8.0 \mathrm{abc}$ & $4.0 \mathrm{cde}$ & 82abcd & $4.1 \mathrm{bc}$ & $5.6 \mathrm{abcd}$ \\
\hline Vir 51516 & 33 & $7.1 \mathrm{~cd}$ & 7.0cde & $2.9 \mathrm{e}$ & $84 a b c$ & $4.8 \mathrm{ab}$ & 5.1abcd \\
\hline Vir 50929 & 33 & $7.0 \mathrm{~cd}$ & $7.5 \mathrm{bcd}$ & $4.5 \mathrm{bcde}$ & $82 \mathrm{abcd}$ & $4.4 \mathrm{bc}$ & $4.6 \mathrm{~cd}$ \\
\hline LVA 02526 & 34 & $7.0 \mathrm{~cd}$ & $8.0 \mathrm{abc}$ & $3.4 \mathrm{cde}$ & $80 \mathrm{bcd}$ & $6.5 \mathrm{a}$ & $4.9 \mathrm{bcd}$ \\
\hline LIA 1058 & 34 & $7.0 \mathrm{~cd}$ & $6.0 \mathrm{e}$ & $4.1 \mathrm{cde}$ & 84abcd & $4.2 \mathrm{bc}$ & $3.7 \mathrm{~d}$ \\
\hline 155238 & 33 & $6.4 \mathrm{~d}$ & $6.5 \mathrm{de}$ & $4.0 \mathrm{cde}$ & $81 \mathrm{abcd}$ & $4.4 \mathrm{bc}$ & $6.5 \mathrm{abc}$ \\
\hline Raminta & 34 & $6.5 \mathrm{~d}$ & $7.0 \mathrm{cde}$ & $4.0 \mathrm{cde}$ & $87 \mathrm{abc}$ & $4.4 \mathrm{bc}$ & $6.9 \mathrm{ab}$ \\
\hline Saikava & 31 & $9.0 \mathrm{a}$ & $8.5 \mathrm{ab}$ & $4.9 \mathrm{bcd}$ & $81 \mathrm{abcd}$ & $3.8 \mathrm{bcd}$ & $6.8 \mathrm{ab}$ \\
\hline Vizule & 31 & $8.1 \mathrm{~b}$ & $7.5 \mathrm{bcd}$ & $5.0 \mathrm{bcd}$ & $81 \mathrm{abcd}$ & $4.5 \mathrm{bc}$ & $7.0 \mathrm{a}$ \\
\hline $\mathrm{LSD}_{0.05}$ & 1.4 & 0.54 & 0.75 & 1.38 & 7.7 & 1.41 & 1.51 \\
\hline
\end{tabular}

$* a, b, c, \ldots-$ Mean values followed by different letters in each column differ significantly from each other at the $p<0.05$; $* *$ LY - ley year

moderate -3.8 points for 'Saikava' and 4.5 points for 'Vizule'. In the $2^{\text {nd }}$ ley year, the weather conditions were such that a pronounced outbreak of rust infection was not provoked, but in autumn significant differences in terms of greening or sward health there were observed, the ratings ranged from 3.7 to 7.1 points. The healthiest swards were developed by Lp 'Ovambo' (7.1) and 'Raminta' (6.9); and Fl 'Vizule' (7.0) and 'Saikava' (6.8) (Table 1).

The average dry matter (DM) yield in the two years of use ranged from 9.06 to $11.4 \mathrm{t} \mathrm{ha}^{-1}$, depending on the genotype. More productive were Lp 'SW Birger' and 'Elena DS'; significantly $(p<0.05)$ lower DM yield was found for Lp 'No 155238', 'EST 158', and 'Ovambo 1' (Table 2). Usually in the $1^{\text {st }}$ ley year perennial ryegrass grows particularly intensively; however, the prolonged drought in 2019 contributed to only three harvests. In the $2^{\text {nd }}$ ley year, the humidity conditions were much more favorable, there was a possibility to harvest four mowings. If we compare the average yields of $\mathrm{Lp}$ and Fl, it can be concluded that there were no significant DM yield differences in the first two years. Slightly higher DM yield on average in the $1^{\text {st }}$ and $2^{\text {nd }}$ ley year was provided by Fl: $10.96 /$ 10.56 and $10.32 / 10.05 \mathrm{t} \mathrm{ha}^{-1} \mathrm{Fl} / \mathrm{Lp}$, respectively. Productivity and persistence of forage grasses is mainly determined by the genetic potential of species and varieties (Moser \& Hoveland, 1996).

The highest proportion of DM yield, similar to other grass species, perennial ryegrass provides in the $1^{\text {st }}$ harvest. In this experiment, the average DM yield of the $1^{\text {st }}$ cut was $58 \%$ of the total DM yield (Figure 2). Depending on the genotype, it slightly varied between 56 and $62 \%$, calculated on the basis of the average DM yield over two years. The yield proportion of the $2^{\text {nd }}$ and $3^{\text {rd }}$ harvests were relatively similar, $21 \%$ and $17 \%$, respectively (Figure 2 ). The $4^{\text {th }}$ harvest in the $2^{\text {nd }}$ ley year was only $4 \%$ of the total yield. Although sometimes the last harvest does not give a significant increase in the total yield, it is important to mow it in 
Dry matter yield of $L$. perenne and $\times$ Festulolium varieties and genebank accessions in two ley years

\begin{tabular}{|c|c|c|c|c|}
\hline \multirow{2}{*}{ Genotype } & \multirow{2}{*}{$1^{\text {st }}$ ley year, $\mathrm{tha}^{-1}$} & \multirow{2}{*}{$2^{\text {nd }}$ ley year, $\mathrm{t} \mathrm{ha}^{-1}$} & \multicolumn{2}{|c|}{ An average in two ley years } \\
\hline & & & $\mathrm{t} \mathrm{ha}^{-1}$ & $\%$ to control \\
\hline \multicolumn{5}{|l|}{ Lolium perenne $(\mathrm{Lp})$} \\
\hline SW Birger & $11.48^{\mathrm{ab}}$ & $11.27^{\mathrm{ab}}$ & $11.38^{\mathrm{a}}$ & 100 \\
\hline Raite & $10.13^{\mathrm{bc}}$ & $10.48^{\mathrm{abc}}$ & $10.30^{\mathrm{abcd}}$ & 91 \\
\hline Elena DS & $11.30^{\mathrm{ab}}$ & $11.50^{\mathrm{a}}$ & $11.40^{\mathrm{a}}$ & 100 \\
\hline Alduva & $10.35^{\mathrm{abc}}$ & $10.46^{\mathrm{abc}}$ & $10.40^{\mathrm{abcd}}$ & 91 \\
\hline Verseka & $10.88^{\mathrm{abc}}$ & $10.14^{\mathrm{abc}}$ & $10.51^{\mathrm{abcd}}$ & 92 \\
\hline Garbor & $12.15^{\mathrm{a}}$ & $9.87^{\mathrm{abc}}$ & $11.01^{\mathrm{ab}}$ & 97 \\
\hline Ovambo 1 & $9.70^{\mathrm{bc}}$ & $9.01^{\mathrm{bc}}$ & $9.35^{\mathrm{bcd}}$ & 82 \\
\hline Vifelt & $10.75^{\mathrm{abc}}$ & $10.50^{\mathrm{abc}}$ & $10.62^{\mathrm{abcd}}$ & 93 \\
\hline LIA 58 & $10.32^{\mathrm{bc}}$ & $9.40^{\mathrm{abc}}$ & $9.86^{\text {abcd }}$ & 87 \\
\hline Vir 50774 & $10.76^{\mathrm{abc}}$ & $10.24^{\mathrm{abc}}$ & $10.50^{\mathrm{abcd}}$ & 92 \\
\hline EST 158 & $9.36^{\mathrm{c}}$ & $9.07^{\mathrm{bc}}$ & $9.21^{\mathrm{cd}}$ & 81 \\
\hline Vir 51515 & $10.48^{\mathrm{abc}}$ & $10.04^{\mathrm{abc}}$ & $10.26^{\mathrm{abcd}}$ & 90 \\
\hline EST 50 & $11.27^{\mathrm{ab}}$ & $10.96^{\mathrm{abc}}$ & $11.12^{\mathrm{a}}$ & 98 \\
\hline Vir 51516 & $9.96^{\mathrm{bc}}$ & $10.51^{\mathrm{abc}}$ & $10.23^{\mathrm{abcd}}$ & 90 \\
\hline Vir 50929 & $10.76^{\mathrm{abc}}$ & $9.83^{\mathrm{abc}}$ & $10.29^{\mathrm{abcd}}$ & 90 \\
\hline LVA02526 & $10.14^{\mathrm{bc}}$ & $9.96^{\mathrm{abc}}$ & $10.05^{\mathrm{abcd}}$ & 88 \\
\hline LIA 1058 & $10.99 \mathrm{abc}$ & $8.98^{\mathrm{bc}}$ & $9.99^{\mathrm{abcd}}$ & 88 \\
\hline No155238 & $9.30^{\mathrm{c}}$ & $8.81^{\mathrm{c}}$ & $9.06^{\mathrm{d}}$ & 80 \\
\hline Raminta & $10.57^{\mathrm{abc}}$ & $9.87^{\mathrm{abc}}$ & $10.22^{\mathrm{abcd}}$ & 90 \\
\hline \multicolumn{5}{|l|}{ Festulolium (Fl) } \\
\hline Saikava & $11.18^{\mathrm{ab}}$ & $10.52^{\mathrm{abc}}$ & $10.85 \mathrm{a}^{\mathrm{bc}}$ & 95 \\
\hline Vizule & $10.73^{\mathrm{abc}}$ & $10.11^{\mathrm{abc}}$ & $10.42^{\mathrm{abcd}}$ & 92 \\
\hline An average of $L p$ & 10.56 & 10.05 & 10.30 & \\
\hline An average of Fl & 10.96 & 10.32 & 10.64 & \\
\hline LSD0.05 & 1.32 & 1.72 & 1.26 & \\
\hline
\end{tabular}

$* a, b, c, \ldots-$ The mean values in each column followed by different letters differ significantly from each other at the $\mathrm{p}<0.05$

order to provide better overwintering. It is known that large green mass, left for the winter, can cause snow mold and other infectious diseases, which generally worsen winter hardiness and, consequently, the persistence. The forage quality of the $1^{\text {st }}$ mowing was evaluated. The content of crude protein $(\mathrm{CP})$ ranged from 6.99 to $10.68 \%$ for Lp; slightly lower (7.84 to $8.31 \%$ ) it was for $\mathrm{Fl}$ (Table 3$)$. The highest $(>10 \%)$ $\mathrm{CP}$ content was provided by $\mathrm{Lp}$ genotypes 'LIA 1058' and 'Vir 51515'. The ADF fraction negatively correlated with the digestibility of ingested feed. On the other hand, with increase of NDF content its intake decreases. For high-quality dairy cows, the ADF should not exceed $40 \%$ in the dry matter, while the NDF should be below 50\%. Exceeding these values for fiber fractions in fodder will result in less food being eaten and less processing of what is eaten. In this experiment, the $\mathrm{ADF}$ for $\mathrm{Lp}$ ranged from $19.92 \%$ to $25.11 \%$, while the NDF ranged from 38.79 to $46.74 \%$. This proves that Lp provides a high-quality fodder. The dry matter value of interspecific hybrids 'Saikava' and 'Vizule' was also high enough. Net energy for lactation (NEL), which is very important for dairy cows ration compilation, was relatively similar for all genotypes, ranging from 6.6 to $7.02 \mathrm{MJ} \mathrm{kg}^{-1}$. Dry matter digestibility ranged from 69.34 to $73.38 \%$. Dry matter intake (DMI) indicates the amount of dry matter that an animal will be able to eat. It depends on how quickly the fodder is digested and passes through the intestinal tract. This indicator is most directly affected by NDF - as NDF increases, fodder DM intake capacity decreases. In the experiment the DMI ranged from 2.57 to $3.09 \%$ of cow body weight. 


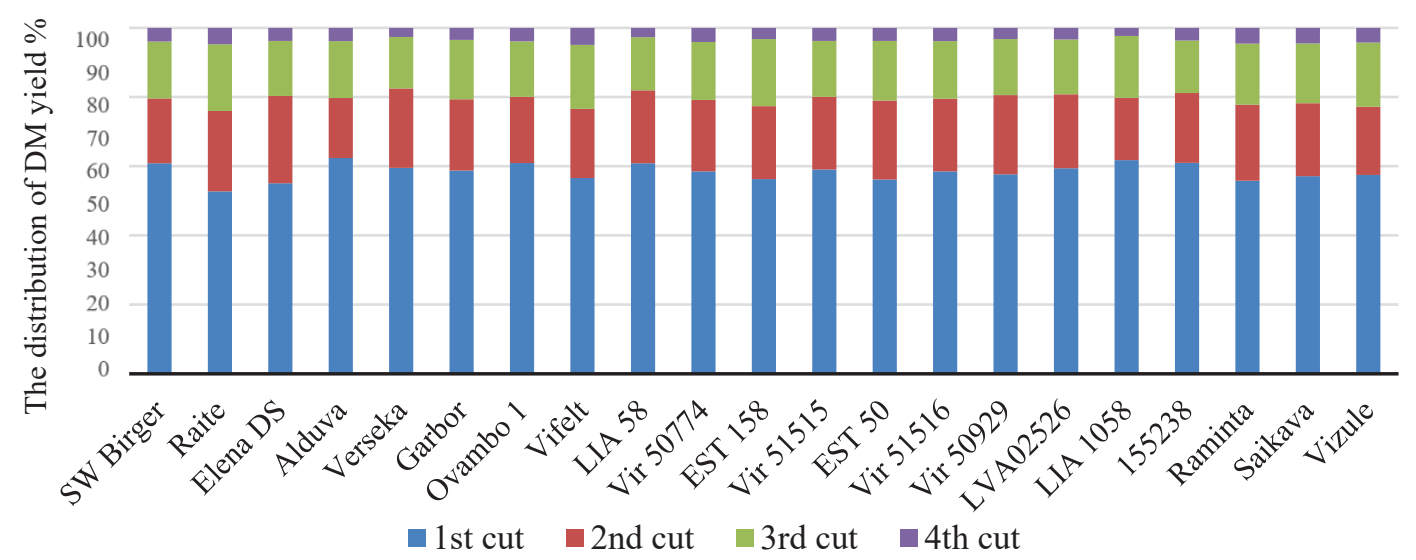

Figure 2. The distribution of dry matter (DM) yield by mowings in two ley years.

The Relative Feed Value (RFV) index is used to feed is considered to be of low quality (Summary of compare feed, taking into account the digestibility and feed..., 2013). High-yielding dairy cows need a feed intake of the feed. The higher this index, the higher with an index above 124. In the experiment, for Lp it the value of fodder. The threshold is 100, below which was significantly higher and ranged between 149 and

Fodder quality of the $1^{\text {st }}$ cut of Lolium perenne and $\times$ Festulolium genotypes

\begin{tabular}{|c|c|c|c|c|c|c|c|c|c|}
\hline Genotype & $\begin{array}{c}\text { Crude } \\
\text { protein, \% }\end{array}$ & $\begin{array}{c}\mathrm{NDF}, \\
\%\end{array}$ & $\begin{array}{c}\mathrm{ADF}, \\
\%\end{array}$ & $\begin{array}{l}\text { NEL, } \\
\mathrm{MJ} \mathrm{kg}^{-1}\end{array}$ & $\begin{array}{l}\text { NEM, } \\
\text { MJ kg-1 }^{-1}\end{array}$ & $\begin{array}{c}\text { NEG, MJ } \\
\mathrm{kg}^{-1}\end{array}$ & $\begin{array}{c}\text { DM } \\
\text { digesti- } \\
\text { bility, \% }\end{array}$ & $\begin{array}{c}\text { DMI, \% of } \\
\text { cow body } \\
\text { weight }\end{array}$ & RFV \\
\hline W Birger & 9.09 & 42.75 & 23.85 & 6.71 & 7.34 & 4.32 & 70.32 & 2.81 & 153 \\
\hline Garbor & 7.15 & 39.01 & 19.92 & 7.02 & 7.71 & 4.69 & 73.38 & 3.08 & 175 \\
\hline Raite & 9.59 & 44.05 & 23.61 & 6.73 & 7.36 & 4.34 & 70.51 & 2.72 & 149 \\
\hline Elena DS & 7.16 & 42.57 & 22.75 & 6.79 & 7.45 & 4.43 & 71.18 & 2.82 & 156 \\
\hline Alduva & 7.71 & 42.08 & 21.95 & 6.86 & 7.52 & 4.50 & 71.80 & 2.85 & 159 \\
\hline Verseka & 6.99 & 40.07 & 21.75 & 6.87 & 7.54 & 4.52 & 71.96 & 2.99 & 167 \\
\hline Ovambo 1 & 7.40 & 42.17 & 21.85 & 6.87 & 7.53 & 4.51 & 71.88 & 2.85 & 159 \\
\hline Vifelt & 9.14 & 38.79 & 21.94 & 6.86 & 7.52 & 4.50 & 71.81 & 3.09 & 172 \\
\hline LIA 58 & 8.29 & 43.91 & 22.95 & 6.78 & 7.43 & 4.41 & 71.02 & 2.73 & 150 \\
\hline Vir 50774 & 9.44 & 42.77 & 23.38 & 6.74 & 7.39 & 4.37 & 70.69 & 2.81 & 154 \\
\hline EST 158 & 7.96 & 41.95 & 21.86 & 6.87 & 7.53 & 4.51 & 71.87 & 2.86 & 159 \\
\hline Vir 51515 & 10.10 & 41.36 & 21.72 & 6.88 & 7.54 & 4.52 & 71.98 & 2.90 & 162 \\
\hline EST 50 & 8.42 & 42.15 & 22.31 & 6.83 & 7.49 & 4.47 & 71.52 & 2.85 & 158 \\
\hline Vir 51516 & 7.56 & 41.80 & 22.60 & 6.81 & 7.46 & 4.44 & 71.29 & 2.87 & 159 \\
\hline Vir 50929 & 8.85 & 39.67 & 20.82 & 6.95 & 7.63 & 4.61 & 72.68 & 3.02 & 170 \\
\hline LVA02526 & 7.93 & 43.18 & 22.86 & 6.79 & 7.44 & 4.41 & 71.09 & 2.78 & 153 \\
\hline LIA 1058 & 10.68 & 40.24 & 21.37 & 6.90 & 7.58 & 4.56 & 72.25 & 2.98 & 167 \\
\hline No155238 & 9.29 & 42.42 & 22.43 & 6.82 & 7.48 & 4.46 & 71.43 & 2.83 & 157 \\
\hline Raminta & 9.90 & 41.97 & 22.26 & 6.83 & 7.49 & 4.47 & 71.56 & 2.86 & 159 \\
\hline Saikava & 7.84 & 46.74 & 25.11 & 6.61 & 7.22 & 4.20 & 69.34 & 2.57 & 138 \\
\hline Vizule & 8.31 & 45.07 & 24.01 & 6.69 & 7.33 & 4.31 & 70.20 & 2.66 & 145 \\
\hline An average & 8.51 & 42.13 & 22.44 & 6.82 & 7.48 & 4.45 & 71.89 & 2.85 & 158 \\
\hline Min & 6.99 & 38.79 & 19.92 & 6.61 & 7.22 & 4.20 & 69.34 & 2.57 & 138 \\
\hline Max & 10.68 & 46.74 & 25.11 & 7.02 & 7.71 & 4.69 & 73.38 & 3.09 & 175 \\
\hline
\end{tabular}


175. The RFV index was relatively lower for the Fl 'Saikava' (138) and 'Vizule' (145); however, they also provided high-quality fodder. Assessing the forage quality indicators as a whole, it can be concluded that the highest forage quality was found for $\mathrm{Lp}$ 'Raite', 'Vifelt' and 'Vir 50929'. Other genotypes also performed very well, which confirms that by mowing perennial ryegrass at the begining of heading, it is possible to obtain high-quality fodder.

\section{Conclusions}

Currently, two-year data have been collected, and we can conclude that the highest Lolium perenne (Lp) DM yield proportion is provided in the $1^{\text {st }}$ cut giving $58 \%$ of the total DM yield. The yields of the $2^{\text {nd }}$ and $3^{\text {rd }}$ cuts were similar, $21 \%$ and $17 \%$, respectively. Lp provided satisfactory DM yields - on average 10.56 and $10.05 \mathrm{t} \mathrm{ha}^{-1}$ in the $1^{\text {st }}$ and in the $2^{\text {nd }}$ ley year, respectively. Lp DM yields did not differ significantly from $\times$ Festulolium $(\mathrm{Fl})$.
In the first years of use, no significant differences were found between ryegrass and grass interspecies hybrids in terms of grass quality and forage value. ADF for Lp ranged from $19.92 \%$ to $25.11 \%$, while NDF from $38.79 \%$ to $46.74 \%$. This proves that ryegrass provides high-quality fodder. The Relative Feed Value (RFV) index for Lp was high, it ranged between 149 and 175 , slightly lower it was for Fl, on average 142 .

The research should be continued to determine the more persistent and productive genotypes, especially in harsher wintering conditions, as well as to compare the performance of $\mathrm{Lp}$ with $\mathrm{Fl}$ in the later years.

\section{Acknowledgements}

This study was carried out within the framework of the project 'Assessment of pre-breeding material of perennial ryegrass' funded by the Latvia Ministry of Agriculture and implementation of Latvia University of Life Sciences and Technologies research program project 'Agro-ecological assessment of varieties and gene bank accessions of perennial ryegrass in Latvia condition'.

\section{References}

Berzins, P., Jansone, B., Rancane, S., Stesele, V., \& Dzene, I. (2015). The evaluation of perennial grass cultivars in Latvia condition. In Nordic View to Sustainable Rural Development: Proceedings of the $25^{\text {th }}$ NJF congress, 16-18 June, 2015 (pp. 141-147).

Berzins, P., Rungis, D., Rancane, S., Gailite, A., Belevica, V., Stesele, V., Vezis, I., \& Jansons A. (2018). Yield and genetic composition of Latvian $\times$ Festulolium cultivars and breeding material. In G. Brazauskas et al. (Eds.), Breeding Grasses and Protein Crops in the Era of Genomics (pp. 62-67). Springer, Cham. DOI: 10.1007/978-3-319-89578-9.

Berzins, P., Rungis, D., Rancane, S., Stesele, V., Vezis, I., \& Jansons, A. (2019). Genetic and agronomic analysis of Latvian fescue (Festuca spp.), ryegrass (Lolium spp.) accessions and their hybrids. Proceedings of the Latvian Academy of Sciences, 73 (6), 487-493. DOI: 10.2478/prolas-2019-0075.

Ghesquière, M., Humphreys, M., \& Zwierzykowski, Z. (2010). Festulolium hybrids: results, limits and prospects. In C. Huyghe (Eds.), Sustainable Use of Genetic Diversity in Forage and Turf Breeding. (pp. 495-507). Springer, Dordrecht. DOI: 10.1007/978-90-481-8706-5_74.

Gutmane, I., \& Adamovics, A. (2008). Analysis of Festulolium and hybrid ryegrass (Lolium x boucheanum) dry matter stability. In Biodiversity and Animal Feed. Future Challenges for Grassland Production, 9-12 June 2008 (pp. 248-250). European Grassland Federation, Uppsala, Sweden.

Halling, M.A. (2012). Yield stability of Festulolium and perennial ryegrass in southern and central Sweden. In Grassland - a European resource? 3-7 June 2012 (pp. 118-120). European Grassland Federation, Uppsala, Sweden.

Helgadóttir, Á., Aavola, R., Isolahti, M., Marum, P., Persson, C., Aleliunas, A., ... Rognli, O.A. (2018). Adaptability and phenotypic stability of Lolium perenne L. cultivars of diverse origin grown at the margin of the species distribution. Journal of Agronomy and Crop Science, 204(5), 493-504. DOI: 10.1111/ jac. 12273 .

Kemešytė, V., Statkevičiūtè, G., \& Jaškūnè, K. (2019). Long-term crown rust survey in perennial ryegrass and Festulolium trials in Lithuania. In improving sown grasslands through breeding and management. 24-27 June 2019 (pp. 429). European Grassland Federation, Zürich, Switzerland.

Lemežienė, N., Kanapeckas, J., Tarakanovas, P., \& Nekrošas, S. (2004). Analysis of dry matter yield structure of forage grasses. Plant Soil Environ. 50: 277-282. DOI: 10.17221/4033-PSE.

Lee, M.A., Howard-Andrews, V., \& Chester, M. (2019). Resistance of multiple diploid and tetraploid perennial ryegrass (Lolium perenne L.) varieties to three projected drought scenarios for the UK in 2080. Agronomy. 9(3), 1-7. DOI: 10.3390/agronomy9030159.

McClearn, B., Gilliland, T., Guy, C., Dineen, M., Coughlan, F., \& McCarthy, B. (2019). The effect of perennial ryegrass ploidy and white clover inclusion on milk production of dairy cows. Animal Production Science, 60(1), 143-147. DOI: 10.1071/AN18539. 
Moser, L.E., \& Hoveland, C.S. (1996). Cool Season Grass Overview. In L.E. Moser, D.R. Buxton \& M.D. Casler (Eds.), Cool Season Forage Grasses (pp. 1-14). Soil Science Society of America, Madison, Wisconsin. DOI: 10.2134/agronmonogr34.

Nekrošas, S., \& Kemešytė, V. (2007). Breeding of Ryegrass and Festulolium in Lithuania. Žemdirbystė/ Agriculture, 94(4), 29-39.

O’Donovan, M., \& Delaby, L. (2005). A comparison of perennial rye-grass cultivars differing in heading date and grass ploidy with spring calving dairy cows grazed at two different stocking rates. Animal Research, 54(5), 337-350. DOI: 10.1051/animres:2005027.

Østrem, L., Volden, B., \& Larsen, A. (2013). Morphology, dry matter yield and phenological characters at different maturity stages of $\times$ Festulolium compared with other grass species. Acta Agriculturae Scandinavica, 63, 531-542. DOI: 10.1080/09064710.2013.819440.

Østrem, L., Novoa-Garrido, M., \& Larsen, A. (2013). Festulolium - an interesting forage grass for high-latitude regions? In The Role of Grasslands in a Green Future. Threats and Perspectives in Less Favoured Areas: 23-26 June 2013 (pp. 270-272). European Grassland Federation, Agricultural University of Iceland.

Rancane, S., Rungis, D.E., Kreismane, Dz., Vezis, I., Rebane, A., \& Jansons, A. (2021). Assessment of Lolium perenne tetraploid clones produced from a diverse diploid breeding population. Zemdirbyste-Agriculture, 108(1), 35-42. DOI: 10.13080/z-a.2021.108.005.

Rongli, O.A., Aavola, R., Aleliūnas, A., Asp, T., Brazauskas, G., Gylstrøm, K.H., ... Rancāne, S. (2018). Utilization of genebank accessions to improve northern adaptation of perennial ryegrass. In G. Brazauskas et al. (Eds.): Breeding Grasses and Protein Crops in the Era of Genomics (pp. 3-8). Springer, Cham. DOI: 10.1007/978-3-319-89578-9_1.

Rognli, O.A., Fjellheim, S., Pecetti, L., \& Boller, B. (2013). Semi-natural grasslands as a source of geneticdiversity. In The Role of Grasslands in a Green Future. Threats and Perspectives in Less Favoured Areas: 23-26 June 2013 (pp. 303-313). European Grassland Federation, Agricultural University of Iceland. Schubiger, F.X., Baert, J., Bayle, B., Bourdon, P., Cagas, B., Cernoch, V., ... Boller, B. (2010). Susceptibility of European cultivars of Italian and perennial ryegrass to crown and stem rust. Euphytica, 176, 167-181.

Schubiger, F.X., Baert, J., Bayle, B., ..., Boller, B. (2010). Susceptibility of European cultivars of Italian and perennial ryegrass to crown and stem rust. Euphytica, 176: pp. 167-181.

Summary of feed analysis results. (2013). Retrieved February 9, 2021, from http://www.laukutikls.lv/sites/ laukutikls.lv/files/upload/piena_rokasgramata/54_lopbariba_internetam.pdf(in Latvian).

Tubritt, T., Delaby, L., Gilliland, T., \& O’Donovan, M. (2020). An investigation into the grazing efficiency of perennial ryegrass varieties. Grass and Forage Science. 75(3), 253-265. DOI: 10.1111/gfs.12481.

WRB. (2014). World reference base for soil resources. World Soil Resources Reports No. 106. FAO, 189 p. 